\title{
Mission unstoppable? - the full empowerment of women
}

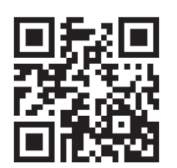

In this Women's Month there is much to reflect on regarding the status of youth, and particularly girls and young women, in the world.

Former British Prime Minister Gordon Brown, serving as United Nations Special Envoy for Global

Education, used 16 June, South Africa (SA)'s Youth Day but now marked around the world as The Day of the African Child, to urge the world 'not to forget the 200 Chibok schoolgirls and to promote the Safe Schools Initiative - aimed at providing safe schools for every girl and boy.[1] He pledged, with Nigerian President Goodluck Jonathan and Finance Minister Ngozi Okonjo-Iweala, that the school from which the girls were kidnapped by Islamist militants belonging to Boko Haram (which opposes schools that teach a so-called Western curriculum) will be rebuilt. Such atrocities continue.

From our own Phumzile Mlambo-Ngcuka, Executive Director of UN Women, we learn in her statements to the UN Security Council of rape, sexual slavery, and other violations perpetrated by armed forces in the Central African Republic; of the assassination of the Libyan leader and women's rights advocate Salwa Bugaighis, killed soon after casting her vote in the recent Libyan election, a right she fought for as a member of the National Transitional Council during the 2011 revolution; and, most recently, of the deliberate targeting of women and girls in Iraq and reports of kidnapping, rape and forced marriage by militants of the Islamic State of Iraq and the Levant and other armed groups (received via emails from UN Women, 27 June and 1 July 2014).

SA chose the 2014 Youth Day celebrations to call for quality education, proposing that Youth Month be celebrated under the theme 'Youth Moving South Africa Forward. ${ }^{[2]}$ Deputy President Cyril Ramaphosa ${ }^{[3]}$ agreed with the Each One Teach One Foundation that 'Our schooling environment (in Soweto) is plagued by drug abuse, religious maladies like Satanism, violence including rape and murder, financial challenges and collapsing infrastructure,' and remarked that SA youth are particularly vulnerable to unemployment, poverty, inequality and low skills levels. Youth unemployment - more than a third of SA youth is unemployed - poses a critical challenge for our country. The hope, Ramaphosa stated, is that if we can effectively address youth unemployment, we will lift millions of South Africans out of poverty, and place our economy on a trajectory of sustainable, inclusive growth'

The same week saw the Global Summit to End Sexual Violence in Conflict, led by Hollywood actress and UN special envoy Angelina Jolie and UK Foreign Minister William Hague, to deal with the scourge of rape as a weapon of war. The World Health Organization estimates that 150 million women and girls are raped every year in conflict zones (see figure, 'Where is sexual violence happening in conflict zones?', p. 519). So are 73 million men and boys. ${ }^{[4]}$

The presence of Jolie lent a cachet to the meeting, which brought together 129 country delegations, including 79 ministers. The mandate was to agree practical steps to bring an end to impunity - 'when rape victims start to see the people who abused them pay for their crimes, the world will undergo a sea change. ${ }^{[5,6]}$ In her Birthday Honours, Queen Elizabeth II bestowed an honorary damehood on Jolie for her work combating sexual violence in war zones; Jolie plans to apply for Namibian (read Commonwealth) citizenhood, so that she may exploit the title in her humanitarian work. ${ }^{[7]}$
Hague stated in closing the meeting: 'We have tolerated and still do tolerate violence and discrimination against women in many forms in all quarters of the world, and women still do not occupy their rightful place in the economics, in diplomacy and government of many nations. We should not have to be reminded, as governments, that women must have a seat in every forum of decision-making, and it should not be the uphill struggle that it is to overturn the habits of centuries and establish new precedents and norms for full female participation. ${ }^{[8]}$

The policy paper ${ }^{[9]}$ issued by the UK Foreign and Commonwealth Office made clear that 'Sexual violence is not a lesser crime: it is an atrocity of the first order and there must be no safe haven for perpetrators anywhere.' The International Protocol on the Documentation and Investigation of Sexual Violence in Conflict ${ }^{[10]}$ will help to bring perpetrators to justice, and overcome a key barrier to tackling impunity for sexual violence in conflict.

Girls and women are in a precarious position, even in our relatively sophisticated society as measured by the SA Constitution, which is the envy of many countries. Last month's Izindaba carried a piece entitled 'Women doctors have a rougher time'. In acknowledgement of this situation, and in celebration of National Women's Day on 9 August, some 50 women doctors, led by deputy health minister Gwen Ramokgopa, will formally launch an SA Medical Women's Association. ${ }^{[11]}$ As stated, 'with well over half of all medical school graduates now female, there is a serious need to rethink, especially in the public sector, how the healthcare system is geared to embrace this

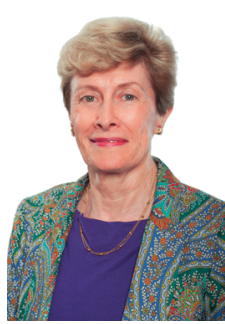
changing reality. We need to look at issues like good security, crèche facilities and job-sharing appointments. ${ }^{\cdot[1]}$

This Women's Month SAMJ contains much of relevance to women's issues.

\section{Janet Seggie}

Editor

janet.seggie@hmpg.co.za

1. UN Envoy Gordon Brown vows new school for kidnapped Nigerian girls. http://www.ndtvcom/article/ world/un-envoy-gordon-brown-vows-new-school-for-kidnapped-nigerian-girls-543379 (accessed 19 June 2014)

2. Youth Day puts quality of education under spotlight. http://www.sabc.co.za/news/a/01e7a0004462f415 8900fd744a7933f3/Youth-Day-puts-quality-of-education-under-spotlight-20141606 (accessed 19 June 2014)

3. Keynote Address by Deputy President Cyril Ramaphosa. http://www.sabc.co.za/news/a/ e8cd78004463b6a290dff47444a7933f3/Keynote-Address-by-Deputy-President-Cyril-Ramaphosa-20141606 (accessed 19 June 2014).

Where is sexual violence happening in conflict zones? http://www.bbc.co.uk/newsbeat/27779468 (accessed 19 June 2014).

Global Summit to End Sexual Violence in Conflict 4. https://www.gov.uk/government/topical-events/ sexual-violence-in-conflict (accessed 19 June 2014).

The Angelina Jolie effect at the sexual violence summit. http://www.theguardian.com/lifeandstyle/ womens-blog/2014/jun/12/the-angelina-jolie-effect-at-the-sexual-violence-summit (accessed 19 June 2014)

7. Queen’s Birthday Honours: Angelina Jolie is appointed a Dame for her campaign to end sexual violence. http://www.independent.co.uk/news/uk/home-news/queens-birthday-honours-angelina-jolie-isappointed-a-dame-for-her-campaign-to-end-sexual-violence-9536120.html (accessed 19 June 2014). Speech: Foreign Secretary closes Global Summit to End Sexual Violence in Conflict. https://www.gov. uk/government/speeches/foreign-secretary-closes-global-summit-to-end-sexual-violence-in-conflict (accessed 19 June 2014)

9. The Policy Paper Chair's Summary - Global Summit to end Sexual Violence in Conflict. https://www gov.uk/government/publications/chairs-summary-global-summit-to-end-sexual-violence-in-conflict/ chairs-summary-global-summit-to-end-sexual-violence-in-conflict (accessed 19 June 2014).

10. Statement of Action - Global Summit to End Sexual Violence in Conflict. From: Foreign \& Commonwealth Office and the Rt Hon William Hague MP. 13 June 2014. https://www.gov.uk/government/publications/ Office and the Rt Hon William Hague MP. 13 June 2014. https://wWw.gov.uk/government/publi
statement-of-action-global-summit-to-end-sexual-violence-in-conflict (accessed 19 June 2014). 11. Bateman C. Women doctors have a rougher time - new association born. S Afr Med J 2014;104(7):463464. [http://dx.doi.org/10.7196/SAMT.8539]

S Afr Med J 2014;104(8):517. DOI:10.7196/SAMJ.8676 